\title{
Herbert Hoover's Early Schooling in Iowa and Its Place in Presidential Politics, Community Memory, and Personal Identity
}

\author{
JAMES QUINTEN CAHILL
}

IN APRIL 1923, when Herbert Hoover, as Secretary of Commerce in President Harding's Cabinet, gave an address to students and others at the new high school in West Branch, he asked that Mollie Brown Carran be seated on the platform beside him. The local newspaper reported that he introduced her as a former teacher of his, but some of those in attendance understood that he had introduced her as his first teacher. ${ }^{1}$ Regardless of whether Hoover intended that meaning or it came from later developments, this event was the first known instance when Hoover singled out Mollie Brown Carran from among his former teachers for special attention and so planted the seed of the subsequent misunderstanding that she was his first teacher. His reference to "the little white schoolhouse" he attended under Miss Brown may also have contributed to subsequent claims that Hoover attended a one-room schoolhouse. Despite being almost universally accepted, both claims - that Hoover's first teacher was Mollie Brown and that he attended a one-room school-

1. "West Branch Welcomes Native Son-Hoover," West Branch Times, 19 April 1923, Acc. 554/2, Maud Stratton Papers, Herbert Hoover Presidential Library, West Branch, Iowa (hereafter cited as HHPL). The newspaper article has some direct quotations of Hoover's words, but no complete text of this early, informal speech has been found. In subsequent citations, when newspaper clippings lack information needed for full citation, dates and other information written in by the Hoover Library staff or that are obvious by the context are placed in brackets.

THE ANNALS OF IOWA 61 (Spring 2002). (C) The State Historical Society of Iowa, 2002. 
house-are contradicted by contemporary documents and by the statements of participants in Hoover's early schooling.

These details may seem of trivial importance in comparison with Hoover's professional and financial success as a young mining engineer and businessman and his later membership in the highest political elite in the United States, as well as his reputation for being the world's greatest humanitarian in the first half of the twentieth century. Several larger issues relate to these two details of his early schooling and help to justify attention to them. The personal lives of political leaders have always been of interest, and politicians' early lives and the way they later describe them help us to understand their personality and character. Another reason for undertaking a new analysis of these details of Hoover's early schooling is the enduring goal of all historians: to increase the accuracy of our knowledge of history.

After examining the contemporary evidence about Hoover's first teacher and first school, this study traces how historical knowledge about Hoover's early schooling became distorted and developed into generally accepted errors in historical understanding. Collections of newspaper clippings provide the main way to track those errors, for journalists had much to do with creating and spreading the misunderstandings. Two final sections propose some likely reasons why error crowded out the documented truth. Political and psychological factors help to explain why Hoover may have chosen not to challenge the errors (and perhaps even encouraged one of them), and sociological factors may explain why the local community went along with both errors. This process is a case study in how an interest in promoting the heritage of an individual and a community can undermine accurate historical understanding.

HERBERT HOOVER, born August 10, 1874, had just turned five years old in September 1879 when his parents started him in first grade in the West Branch school. ${ }^{2} \mathrm{He}$ may have been the

2. Edwin C. Bearss, Historic Furnishing Study: Primary Department of the West Branch School (Denver, 1973), vii, 6-7, 9. This report was based on school records that have since been lost, probably in the 1978 fire that destroyed the 1920 school building. In an earlier work, The Hoover Houses and Community Structures (Denver, 1971), 138, Bearss said that Hoover started school one year later. 


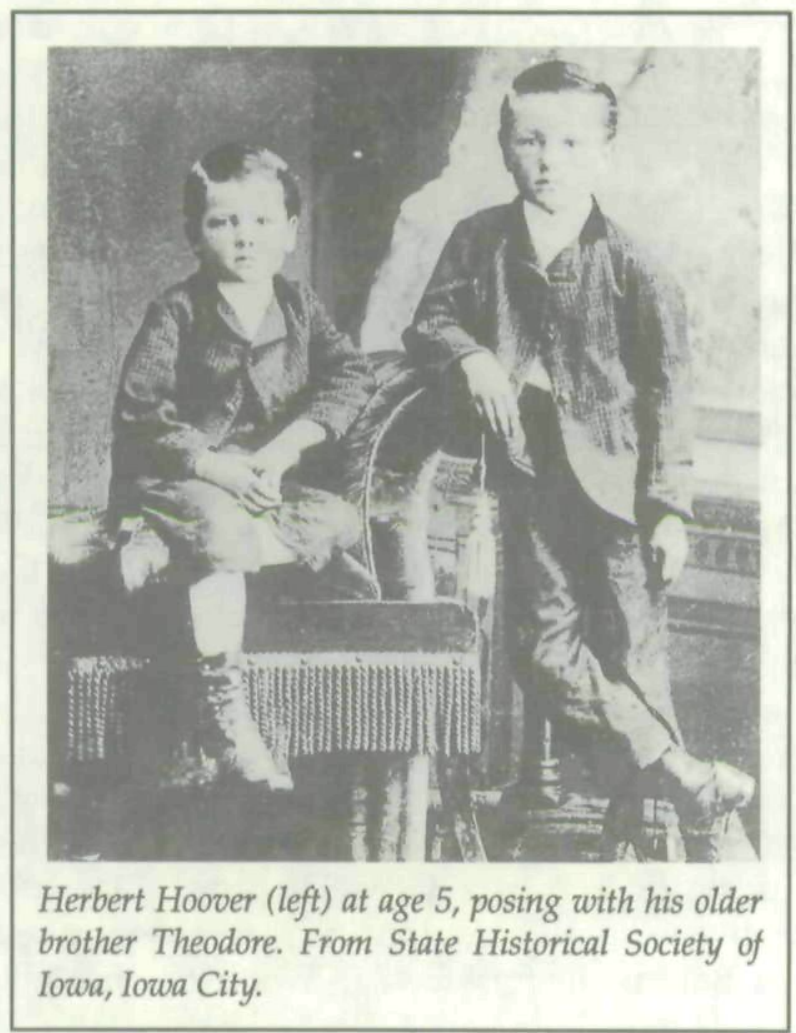

youngest child in the class and probably was not as ready for some of the schoolwork as most of his classmates. ${ }^{3}$ Hoover's first teacher was Lottie Kalb, who was in charge of the primary department and had the first three grades in her classroom. Kalb returned to Denison in western Iowa after that year, and apparently had no further contact with West Branch.

3. One of those first-graders later said that he was about one year older than Hoover. "Newt Butler Tells of Boyhood Association with President Hoover," address to the Washington, Iowa, Rotary Club, Washington [Iowa] Evening Journal, 25 June 1929, Herbert Hoover Scrapbook, 1929, Mollie Brown Carran Papers, HHPL.

4. Bearss, Historic Furnishing Study: Primary Department, 6-7, 9. Bearss wrote that Kalb taught for several years in West Branch, which is confirmed by the newspaper's listing her as the primary teacher for the school year before Hoover started. West Branch Local Record, 5 June 1879. 
Hoover's second grade teacher was Elizabeth Chandler, who taught only that one year in West Branch (1880-81). In December 1880 Hoover's father died, undoubtedly interfering with his schoolwork for the rest of that year. By the end of his third grade year (1881-82), Hoover, even under an experienced teacher, Anna Painter, may have been having trouble with subjects other than arithmetic but still was promoted to fourth grade. ${ }^{6}$

Hoover's school progression then stopped for two years, due to disruptions of attendance and corresponding lack of achievement. It appears that Hoover attended most of his fourth grade school year, 1882-83, although many years later he described a visit to the Southwest that could have included much of the school year. Hoover wrote, "an uncle, Major Laban Miles, took me to then Indian Territory for eight or nine months, where I lived with the family." ${ }^{\prime \prime}$ This visit, however, probably occurred during the summer of 1883 . When Hoover's wife, Lou Henry, asked her husband's cousin and contemporary, Harriet Miles Odell, about the timing of his visit to Indian Territory, she replied, "Bert's visit to us . . . was the summer previous to his mother's death [in February 1884]. He came with Father who was returning from Washington in May. He returned home late in Sept. but in time for school. ${ }^{18}$ Two letters from Hoover's

\section{Bearss, Historic Furnishing Study: Primary Department, 6-7, 9.}

6. Ibid., 6-10. Hoover's last teacher at West Branch was quoted as saying, "He was an average good student, a little quick at arithmetic." "Toss the 'Shoes,' Wait," Kansas City Times, 21 August [1928], Hoover Scrapbook, 1914-1928, Carran Papers.

7. Herbert Hoover, The Memoirs of Herbert Hoover: Years of Adventure, 1874-1920 (New York, 1951), 4. Bearss placed this visit during Hoover's 1881-82 school year, but a later scholar argued convincingly that Hoover could not have been absent that long from West Branch. Bearss, Historic Furnishing Study: Primary Department, 8-10; George H. Nash, The Life of Herbert Hoover: The Engineer, 1874-1914 (New York, 1983), 9. Nash apparently referred to an attendance record available by that time: "Record of Scholars' Attendance and Punctuality During the Term Commencing April 3, 1882 and Ending May 26, 1882," Herbert Hoover School Attendance Record, 1882, Acc. 868, Special CollectionsMemorabilia, Cedar County Collections, HHPL. Another scholar placed the visit "from March until late October 1881," which would have been at the end of his second grade and the beginning of his third grade. David Burner, Herbert Hoover: A Public Life (New York, 1979), 12, 354n.

8. Mrs. Francis F. [Harriette] Odell to Lou [Henry Hoover], 18 October 1939, Genealogy Series, Harriette Miles Odell, 1930-1939, Herbert Hoover Papers, HHPL. 
widowed mother to her sister, Agness Miles, confirm this time frame. Her letter in mid-March 1883 spoke of "the children" as being with her in West Branch, and her October letter indicated that Hoover had been in West Branch since about early October 1883 . $^{9}$ From these dates, it appears that Hoover missed perhaps a month of school in West Branch from early May to school's end in early June, and at least three weeks of the school year that began on September 10, 1883.

Hoover's mother's October letter also hinted that he was having trouble with language and writing skills. Although she wrote, "The children are getting along nicely at school," she added, "I have tried often to get Bertie to write [to you after his visit there] but he always says he can't write good enough." ${ }^{10}$ Probably because of his spotty attendance and achievement, as well as having an ineffective fourth grade teacher, Hoover was not promoted to fifth grade in the fall of 1883 .

Hoover's second start in fourth grade was blessed because he was in the classroom of Mollie Brown, an experienced and effective teacher who had been put in charge of the three intermediate grades. That year, however, was tragic for the Hoover family; Hulda Hoover died in February 1884 and the three orphaned children were sent to live with different relatives. Hoover was sent first to northwest Iowa and was brought back in late April to live with his Uncle Allan and Aunt Millie Hoover on a farm near West Branch."

9. Hulda [Hoover] to Mother and Aggie [Miles], 15 March 1883, ibid.; Hulda R. Hoover to Sister Agness [Miles], 24 October 1883, Hulda Hoover Correspondence, 1861-1883, HHPL.

10. Hulda R. Hoover to Sister Agness [Miles], 24 October 1883, ibid.

11. Maud Stratton, Herbert Hoover's Home Town: The Story of West Branch (n.p., 1948), 53; Nash, Hoover the Engineer, 11, 585n. No records for the 1883-84 school year can now be found; Bearss's reports of the lost school records ended with 1882-83, and no listings of West Branch teachers could be found in the microfilms of damaged and incomplete copies of the local newspaper for 1883-84. Mollie Brown Carran and two of Hoover's former classmates knew that Hoover was in Mollie Brown Carran's classroom when his mother died. "Mollie Carran Keeps Chronicle of Great Man She Once Ruled with Birch Rod," Chicago Tribune, 20 June [1928], Hoover Scrapbook, 1928, Carran Papers; "Newt Butler Tells"; "Little 'Bert' Hoover-As Seen Through the Eyes of His FirstGrade Playmate [Louis Penrose]," The Elkhart Trulth?], datelined Muscatine, Iowa, [1928?], Acc. 554/2, Stratton Papers. Hoover said that Mollie Brown Carran was his teacher "for years," which must include from September 1883 to 
CHRONOLOGY OF HERBERT HOOVER'S SCHOOLING IN WEST BRANCH

\begin{tabular}{lcccc}
\hline Years & Room: Grade* & Teacher & Result & Sources \\
\hline $1879-80$ & Primary: C (1) & Lottie Kalb & completed & registration \\
$1880-81$ & Primary: B (2) & Elizabeth Chandler & completed & registration \\
$1881-82$ & Primary: A (3) & Anna Painter & completed & registration \\
$1882-83$ & Intermediate: C (4) & Ida Albertson & not promoted & registration \\
$1883-84$ & Intermediate: C (4) & Mollie Brown & left in Feb. & 3 witnesses \\
$1884-85$ & Pr.,A \& Int.,C (3\&4) & Mollie Brown & completed 4 & M. Brown \\
$1885-86$ & Intermediate: B (5) & unknown & left Nov. 5 & newspaper \\
\hline
\end{tabular}

* The number in parentheses is the corresponding modern grade number.

After the disruptions in his school attendance in 1883 and 1884, Hoover was sent back to third grade for the 1884-85 school year. The primary and intermediate teachers must have decided that he needed to correct some deficiencies before continuing in the fourth grade for the third time. Mollie Brown, however, offered to take him in her intermediate classroom and help him review the third grade material before taking up the fourth grade work. Her unpublished statement that he was ten years old at the time hints that they may have made this special arrangement for him because he was older than usual for a third grader. ${ }^{12}$ The accommodation saved him from the humiliation of being sent back to the primary classroom; it kept him with his original classmates and friends-now in sixth grade; and it kept him with a familiar teacher who already knew his strengths and weaknesses. That year, 1884-85, Hoover, for the first time in three years, had a complete and successful school year, and apparently was promoted to fifth grade. ${ }^{13}$

February 1884 as well as the full school year 1884-85. Herbert Hoover, "Childhood Recollections of Iowa and Problem of Farm Relief," 21 August 1928, Public Statements, vol. 36, no. 885:2, Hoover Papers; also in Herbert Hoover, $A$ Boyhood in Iowa (New York, 1931), 30-31.

12. [Mollie Brown Carran], "Herbert Hoover: The Boy, The Man, The President," typescript, 1, Acc. 394/3, Carran Papers. An article by Carran in the Christian Science Monitor, 22 August 1928, gave a more favorable explanation of Hoover's promotion: "It was in 1884 and 1885 that he was in my fourth grade. . . . He would have been in the third but he was so industrious that we had to advance him."

13. West Branch Board of Education, The West Branch Consolidated Schools: Its Beginning, Growth, Characteristics and Alumni Record (n.p., 1935). See also the three updates of this school history in 1954, 1965, and 1980. 
Mollie Brown, who had done much to help Hoover start progressing again in school, was both caring and tough. Hoover saw her toughness when he was in a rowdy schoolroom of 35 students, led by a group known as the "Bad Boys," who had run wild under the previous teacher. Hired by school trustees, by her account, "to settle a bunch of boys who had reduced another teacher to hysterics," Mollie Brown entered her first West Branch classroom "with a birch rod under her shawl.,"14

The school board gave the new teacher a free hand, and she used it to win the obedience and respect of the "Bad Boys"and probably of Hoover as well. ${ }^{15}$ As one newspaper reported the story,

There was one boy who sassed her back one day, and, using her authority for corporal punishment, she slapped his face resoundingly. His nose bled over his chin and on the floor, a great mess. The other children, knowing the former rules against a teacher striking, stood trembling. The Quaker president of the board took that moment to visit school. "I shall never forget his face," Mrs. Carran said, laughing heartily. "He looked at the boys huddled together. He looked at my face. He looked at the floor. And then without changing countenance at all he said, "Well, now Mollie, you got our backing, all right, but I do think you ought to stop at blood." ${ }^{16}$

Later pictures showed Mollie Brown Carran as a thin, almost frail, woman, but she said of those difficult and no doubt sometimes large fourth through sixth graders, "None of those boys ever got the best of me. I remember one who would not behave, so I caught both of his hands behind him, tripped him up so he lay on the floor and I put my foot lightly on his hand to hold him there while I continued with the lesson. If he squirmed and tried to get up I just pressed my foot down a little."1

14. "Carran Keeps Chronicle."

15. Apparently she did win their respect, for at the end of that school year, a large group of her former students visited her in her new farm home and had a pleasant day. "'The Old Gang' Is Coming Back," Des Moines Register, 4 August [1928], Stratton Scrapbook 7, Stratton Papers.

16. "Carran Keeps Chronicle."

17. "Old-Fashioned Methods Used to Teach 'Bertie,'" [22 August 1928], Hoover Scrapbook, 1928, Carran Papers. In "Newt Butler Tells," one of the "Bad Boys" confirmed Mollie Brown's methods. 


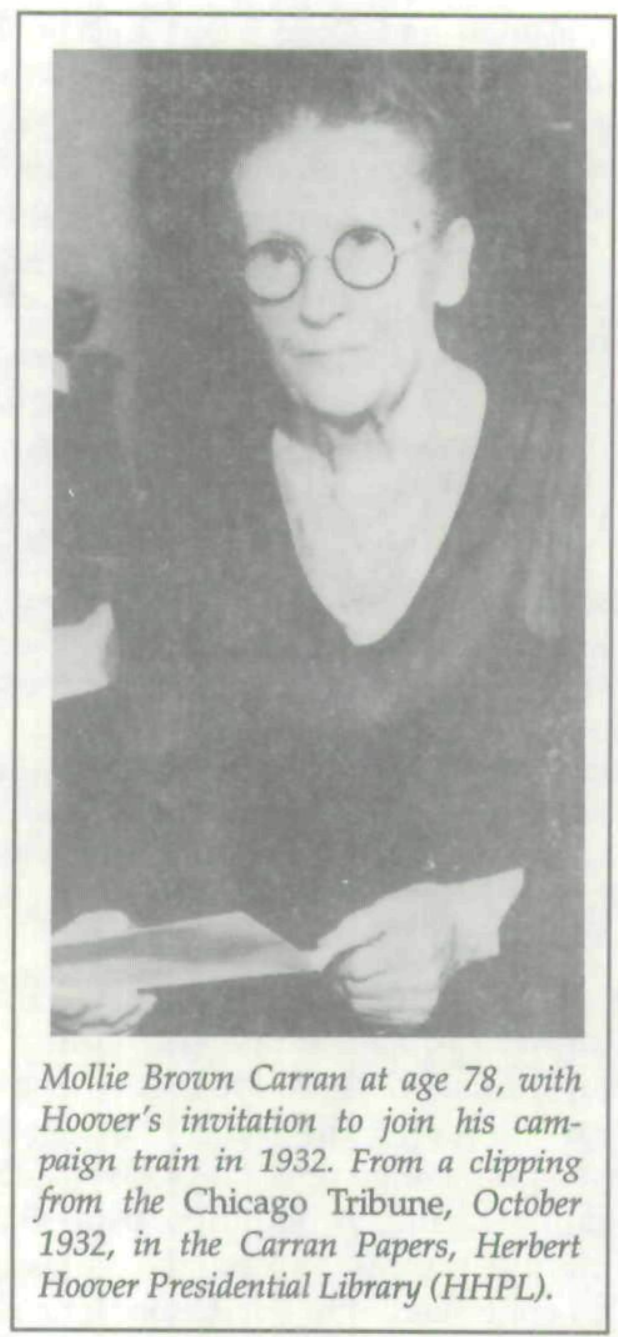

Hoover also saw Mollie Brown's caring help beyond the classroom, as he wrote in his memoirs: "my school-teacher, Mollie Brown-later Mrs. Carran .... strove to secure me for adoption. But Mollie was then unmarried, and the others insisted that family experience was the first necessity for my control. ${ }^{18}$ That probably occurred in late 1884 during Hoover's full year of school with her, as she married John Carran on March

18. Hoover, Memoirs, 1874-1920, 5-6; Nash, Hoover the Engineer, 10-12. 
26,1885 , and by the custom of the time gave up teaching at the end of that term. ${ }^{19}$ Even if the Carrans wanted to adopt Hoover, that possibility was soon removed when several months after their marriage he was sent to live with an uncle in Oregon. ${ }^{20}$ Still, Herbert Hoover had reason not to forget his wonderful teacher and almost his second mother, Mollie Brown Carran.

\section{AS FOR THE SCHOOL that Hoover attended under Mollie} Brown Carran and his other teachers, statements by two contemporary witnesses, in addition to one by his second grade teacher, confirm that Hoover did not attend the one-room schoolhouse built in West Branch in 1853. Speaking at the dedication of a new school in 1905, C. H. Wickersham, who had lived in West Branch since 1865 and whose children had attended school there, said that the one-room schoolhouse, which had been moved from its original downtown site in 1870, was again moved off school property when the main building was expanded in 1877 , two years before Hoover started school in 1879 . When Hoover was running for president in 1928, his classmate Lou Penrose told reporters that he and Hoover "started school together in a fiveroom school." Hoover's second-grade teacher, Elizabeth Chandler Sunier, reported in the same year that "it was to a four-room schoolhouse that he first came."

Around 1970, when the 1853 one-room schoolhouse was to be moved to the grounds of the Herbert Hoover National Historic Site, the scholar Edwin C. Bearss was charged with determining the evidence for the current belief that Hoover had attended school there. The basic question was whether the 1853 schoolhouse was still being used for classes when Hoover

19. Cedar County Historical Society, [Annual], July 1998, 84.

20. Hoover described these as "adoption" offers, but he remained a ward of his Iowa guardian until he reached 21 years of age. Nash, Hoover the Engineer, 42.

21. C. H. Wickersham, "School History," [7 October 1905], typescript, Scrapbook 3 (Community Stories, 1936-1959), Stratton Papers; "First-Grade Playmate," Acc. 554/2, ibid.; "Herbert Hoover Given Right Start by lowa City Woman, His First School Teacher," [Iowa City Press-Citizen], [Summer 1928], Acc. 554/2, Stratton Papers. Wickersham was the owner/editor of the West Branch Local Record (later the Times) from 1878 to 1881 and was West Branch postmaster from 1897 to 1912. The History of Cedar County, with a History of Iowa, 2 vols. (Chicago, 1901), 2:233-34. 


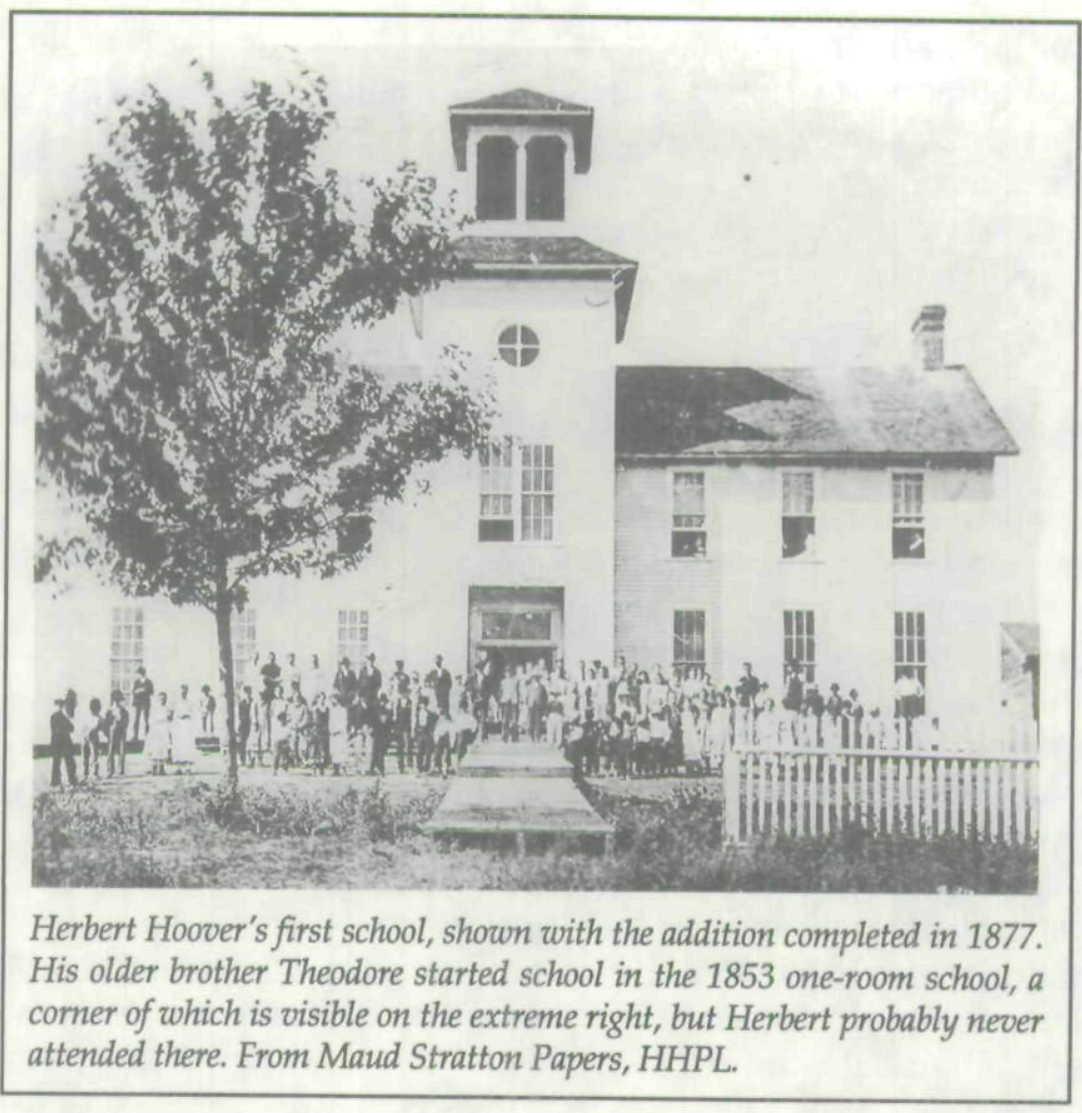

started school in 1879. A photograph (see above) makes it clear that, contrary to Wickersham's statement, the 1853 school was not moved off school grounds immediately after completion of the school expansion in 1877. School records for those years were incomplete, so Bearss, using county and town records, could determine only that the 1853 school building was moved off the school grounds "sometime before 1884." Based on this broad dating, Bearss eventually concluded that, while it was physically possible that Hoover had attended that 1853 schoolhouse, school records "for this period are incomplete, so it is impossible to document" that he ever did so. Bearss's wider finding was that there was no "conclusive evidence that the structure was used as quarters for the primary department subsequent to the construction in 1877" of an addition to the 1867 
building. ${ }^{22}$ In sum, Bearss found no evidence that Hoover had attended the 1853 building, no evidence that the 1853 building had been used as a classroom after 1877 , and no evidence as to when between 1877 and 1884 the 1853 building was moved off school property. Even if that did not happen for several years, however, common sense suggests that a school district would not use an old building just after constructing a large addition.

Unfortunately, Bearss's study left the door open to later confusion. A generation after he filed his report, the brochure at the Herbert Hoover National Historic Site's tourist office makes the following vague and potentially misleading statement about the 1853 one-room school: "It served as the primary school for the West Branch community when Hoover was a boy." ${ }^{\prime 23}$ Although the 1853 building housed the primary school until Hoover was a three-year-old boy, the weight of the existing evidence indicates that he never attended school there.

HOOVER HIMSELF first hinted that Mollie Brown Carran was his first teacher when he praised and honored her, alone among his former teachers, in 1923. Hoover's contact with Carran in 1923 was premeditated. He brought her two gifts: a photograph of himself inscribed, "With kindest regards to Mrs. J. K. Carran," and an autographed card that stated, "To the real founder of character, Miss Mollie Brown, from Herbert Hoover, Feb. 13, 1923." The day after Hoover was nominated for president in June 1928, Carran proudly displayed that picture and card as symbols of her friendship with him. ${ }^{24}$

22. Bearss, Hoover Structures, 138-39, 142, 224 (plate 34); Bearss, Historic Furnishing Study: Primary Department, 5, 9. School records apparently showed that Hoover's older brother Theodore had started school in 1876. According to Bearss, Historic Furnishing Study: Primary Department, 5, Theodore later recalled that he started school in the one-room schoolhouse, and that "a large new school house with several rooms had just been completed." Construction of the 1877 expansion probably took place during Theodore's first grade, 187677, which is likely what he remembered.

23. "Schoolhouse," in Herbert Hoover Historic Site, West Branch, Iowa (Washington, DC, 1999).

24. "'Bertie' Hoover as His West Branch Teacher Knew Him," [Cedar Rapids Gazette], [16 June 1928], Hoover Scrapbook, 1914-1928, Carran Papers; Christian Science Monitor, 22 August 1928; Stratton, Home Town, 111. The photograph is 


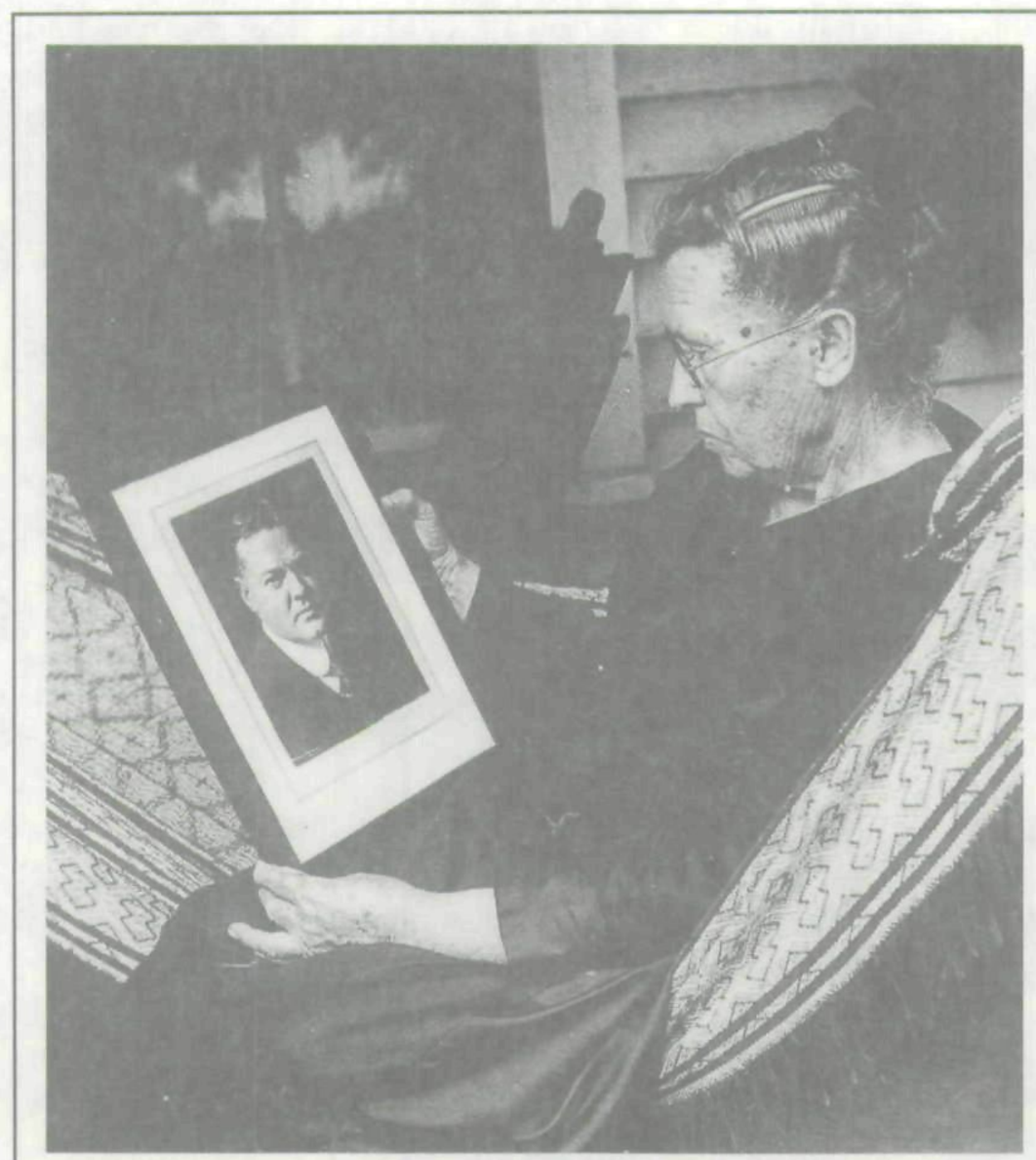

Here Mollie Brown Carran is holding what appears to be the inscribed portrait, now missing, that Herbert Hoover gave her in 1923. Copy from original, courtesy of John and Norma Beecher.

Still, when Hoover returned to West Branch early in his 1928 presidential campaign, Carran did not expect him to call on her. Her plan was to "sit in her backyard ... and see and hear Hoover" on the high school athletic field. She did not plan to go to

not in the Carran Papers at the Herbert Hoover Presidential Library, but there is a photograph of the separate dedication card, about which there is a small mystery. Sometime after Carran's death in 1934 the date on the card was clumsily written over to show "April 13" (the date of Hoover's visit). Scrapbook, 1923-1932, Carran Papers; Obituary, Cedar Rapids Gazette, 16 May 1934. 
the train station to meet the train, "unless particularly requested by the [local] committee. She believes in 'staying in her place.' If no other opportunity presents, she'll meet Mr. Hoover at the reception in the high school." Hoover surprised her by stationing her in one of the two guest seats in his special Lincoln automobile (see cover) and kept her by his side for the public events of the day. ${ }^{25}$

Prior to Hoover's campaign visit to West Branch in August 1928, Mollie Brown Carran was known as his fourth grade teacher. At a political rally, one of Hoover's former classmates, prominent West Branch businessman Fred Albin, introduced her as such. And just before that visit, an article by a local reporter announced, "'The Old Gang' Is Coming Back to See Hoover. Fourth Grade Teacher Adds Her Invitation." That "fourth grade teacher" was identified as "Mrs. J. K. Carran, who as Mollie Brown was teacher of the fourth grade in the days when those lads were together in school. ${ }^{\prime 26}$

Just before Hoover's 1928 visit, Elizabeth Sunier claimed to be his first teacher. An Iowa City newspaper quoted her as saying, "My friends say I must surely have given him the right start." The article explained, "She was a teacher there in 1880 and 1881 . . . . It was to Mrs. Sunier, then Elizabeth Chandler, Quaker, that Herbert Hoover first came to school at the age of six years." That article also referred to him as a "kindergartner," so it clearly intended to say that Lizzie Chandler was Hoover's very first teacher. ${ }^{27}$ None of Hoover's former teachers or classmates is known to have publicly challenged Sunier's claim to be Hoover's first teacher, and Mollie Brown Carran supported it. ${ }^{28}$ In its first historical booklet, the West Branch school board fol-

25. "Toss the Shoes"; "Hoover: The Boy, the Man, the President"; "Historic Picture," 21 August 1928, showing "Mrs. Mollie Carran, Hoover's grade teacher" in the middle-row seat directly ahead of Hoover, [1954 clipping], West Branch Hoover-related clippings, Lawrence Rummels Acc. 579, Cedar County Collections, HHPL; Stratton, Home Town, 126-28.

26. "Hoover-West Branch," West Branch Times, 21 June 1928, Clippings, 19251928, William B. Anderson Papers, HHPL; "'The Old Gang' Is Coming Back."

27. "Hoover Given Right Start by First School Teacher." Sunier left it to the reporter and headline writer to say explicitly that she was Hoover's first teacher.

28. Christian Science Monitor, 4 October 1932. 
lowed local tradition that named Elizabeth Chandler Sunier as Hoover's first teacher. Local journalist-historian Maud Stratton, who helped with the school board's booklet, also believed that Sunier was Hoover's first teacher and never used that description for Mollie Brown Carran. ${ }^{29}$

Despite the local consensus that Elizabeth Chandler had been Hoover's first teacher and that Mollie Brown had taught him in fourth grade, Hoover, by his actions, had already chosen between them. After his election as president, Hoover continued to honor and praise Carran. In addition to giving her special treatment during his visits to West Branch in 1923 and 1928, he honored her during his presidential inauguration celebrations, and she was included in several private meetings and luncheons with the new president and his relatives, as well as a rare picture-taking event with the president's family on the south lawn of the White House. ${ }^{30}$

The growth of honors for Hoover's favorite teacher continued into the summer of 1929. Just two days after Hoover was elected president, an Associated Press report carried this novel and unfounded headline: "Hoover's First Teacher Happy; Mrs. Carran Congratulates 'Bert.' "'31 That headline represented a watershed in press coverage of the issue. The very next day, the Iowa City newspaper that previously had described Elizabeth Sunier as Hoover's first teacher now highlighted Mollie Carran in reporting a celebration in West Branch at which both she and Sunier spoke. The report described Carran as one "whom Herbert Hoover remembered vividly as his teacher of early years, whose influence he has repeatedly lauded." Sunier's speech was mentioned only in the last paragraph, where she was described only generally as "another early teacher of Herbert Hoover." Only three days old, the new error

29. West Branch Board of Education, Schools (n.p., 1935); "Mrs. Mollie Brown Carran Succumbs," West Branch Times, 17 May 1934, Scrapbook 8, 1930-1934, Stratton Papers; Stratton, Home Town, 111, 114; Scrapbook 5, ibid.

30. "Hoover: The Boy, the Man, the President"; Stratton, Home Town, 134-36, 144. 31. "Hoover's First Teacher Happy; Mrs. Carran Congratulates 'Bert,'" 8 November [1928], Scrapbook, 1914-1928, Carran Papers. This article's opening sentence correctly described Carran as "Hoover's early teacher," so the erroneous headline may have been added elsewhere. 


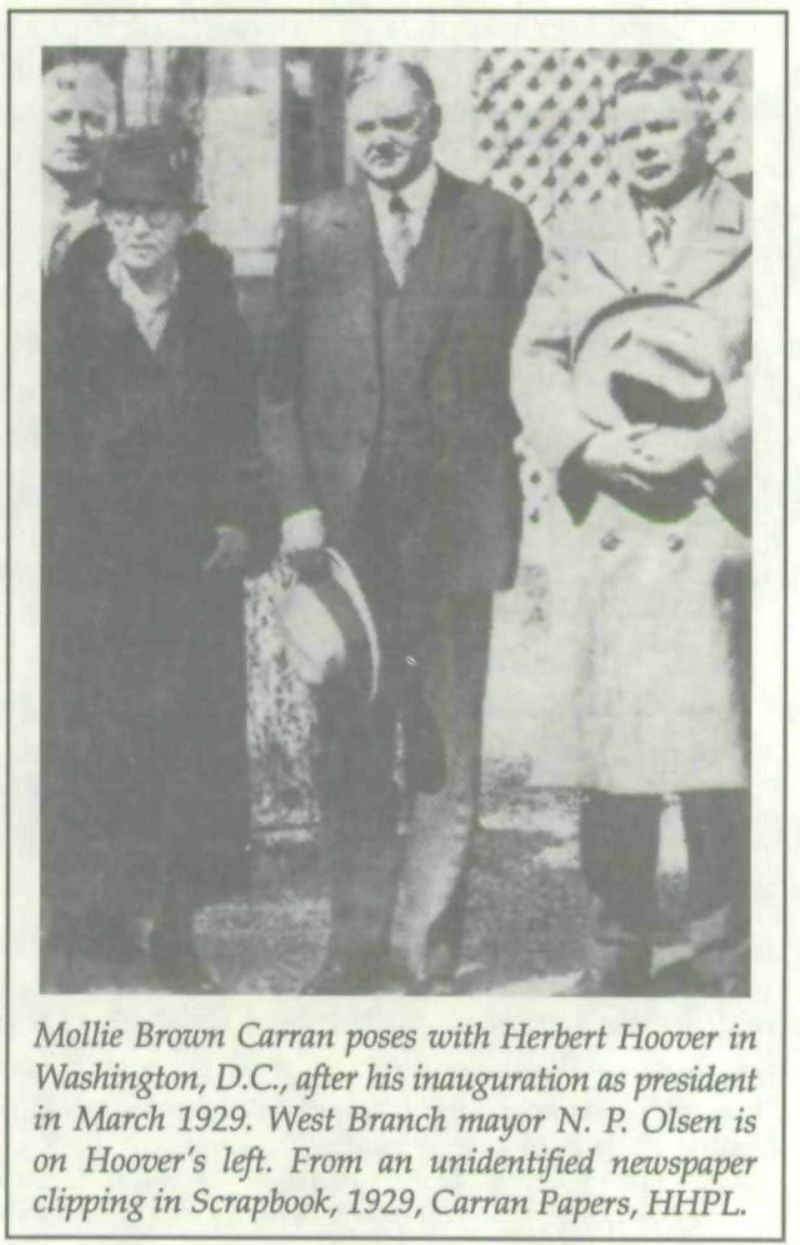

of Mollie Brown as Hoover's first teacher was already sinking roots and spreading. . $^{32}$

Other newspapers also followed the Associated Press's lead. By the end of the summer of 1929 many were describing Mollie Brown Carran as Hoover's first teacher. The claim appeared in a report of the West Branch celebration of Hoover's birthday in early August. During the hot and humid mid-August, the error spread like a weed in reports about Carran, who was the host-

32. "Cheering Crowds Throng West Branch; Celebrate Native Son's Election," [Iowa City Press-Citizen], 9 November 1928, Scrapbook, 1914-1928, Carran Papers. 
ess at the Iowa State Fair's replica of Hoover's birthplace. There were even examples of contradictions within the same article, and one article that described her in the text as Hoover's teacher in third, fourth, or fifth grade carried a headline labeling her as Hoover's first teacher. ${ }^{33}$

During Hoover's 1932 campaign, reporters continued to call Carran his teacher in every grade from first to fifth. Even the White House secretarial staffs in March 1932 first identified her as "a personal friend" and then as "the President's first teacher! ${ }^{\prime 34}$

Hoover himself seemed to repeat the designation by his staff and by the press of Mollie Brown Carran as his first teacher. He invited her to join his train on the way to Des Moines to deliver the main address early in his 1932 campaign. At the stop in West Liberty, they met for the first time in three and a half years, and with photographers present and reportedly with tears in his eyes, Hoover called her "Mrs. Curran [sic], the devoted and self-sacrificing teacher of my first schooling. ${ }^{.135}$

Carran's attitude toward her role as Hoover's honored teacher vacillated between passivity, withdrawal, frustration, and enthusiasm. Immediately after Hoover's nomination, she embraced fame, giving dozens of interviews and photo opportunities, but soon withdrew to her usual social and religious activities, leaving reporters to "fume and fret." ${ }^{136}$ On the eve of

33. See the following newspaper clippings in the Scrapbook, 1929, Carran Papers: "Fragment of Herbert Hoover Birthday Celebration," 10 August 1929; "Oil Painting of His First Teacher," 23 August [1929]; "Mollie Carran to Attend Iowa Fair," [August 1929]; "Tells of Hoover's School Days," Des Moines Register, August 1929.

34. "Invited to Dinner," [14 June 1932], Scrapbook, 1930-1964, Carran Papers; Cedar Rapids Gazette, 4 October 1932, ibid. A clipping fragment, headed "Schoolteacher \& Pupil," [October 1932], described Carran as his first schoolteacher, and then quoted her own contrary words describing Hoover as her pupil in "the year he went to me (in the third grade)." White House descriptions of Carran (with original underlining and exclamation point) were written on her letter to President and Mrs. Hoover, 1 March 1932, and on a copy of the reply of 5 March 1932 by Mrs. Hoover's secretary, both in Personal Correspondence, 1929-1933, Mollie Brown Carran, Lou Henry Hoover Papers, HHPL.

35. Herbert Hoover, "West Liberty Train Stop Remarks," 4 October 1932, Public Statements, vol. 60, no. 1988:1. Several newspaper articles about this train trip are in the Carran Papers.

36. "Tourists Flock to West Branch," clipping, 7 July [1928], Scrapbook, 19141928, Carran Papers. 
Hoover's 1928 campaign visit to West Branch she had not planned to take any steps to meet him privately. After Hoover kept her by his side during that day in West Branch, Carran exulted in her previous efforts on his behalf: "I feel more than repaid for all the trouble I ever took with him just to know that he should have remembered me through all these years." Then, after being showered with more honors at Hoover's inauguration in Washington, D.C., Carran seemed to try to limit her role. In a public address just after returning from there, she took pains to avoid appearing as Hoover's substitute mother or as a rival to his real mother when she said, "I attribute his success mostly to the wonderful influence of his mother and I feel it an honor to have been a guide to him in his childhood. ${ }^{\prime 37}$

Carran at first seemed amused by the way she was being described in the press after Hoover was nominated for president in 1928. She collected and saved those errors along with other clippings, showing a sense of humor similar to that of her husband, who once "came in from the dining room joking about how he got credited in a magazine with being Herbert Hoover's teacher. ${ }^{\prime \prime 3}$ In April 1930, after what she called her "last speaking trip," and after giver her "reading 20 times-Subject 'My Contact with Hoover as a Boy, as a Man, as President,'" she sold the manuscript to Whittier College for fifty dollars. Several months later, she was clearly less tolerant of publicity and did not grant the request of railroad and business promoters to pose as "Hoover's schoolteacher" with the West Branch Tomato Queen. ${ }^{39}$ By the time of Hoover's campaign for re-election in the fall of 1932,

37. "Mollie Carran Journal and Souvenir Booklet," 13 April 1930, Acc. 394/3, Carran Papers; "Toss the Shoes"; "Hoover Expresses Gratitude"; [Address to Cedar Rapids Quota Club, March 1929], Scrapbook, 1929, Carran Papers. See also Carran's unpublished article, "Hoover: The Boy, the Man, the President."

38. "Carran Keeps Chronicle."

39. One of the railroad executives involved in the plans did not even know Carran's name, but wanted a picture of "Hoover's schoolteacher" with the Tomato Queen. During the festival, Carran spoke briefly at the Hoover birthplace and at the luncheon, but the newspaper report has no picture of her with the Tomato Queen. Wm. B. Anderson, Pres. West Branch Com. Club, to George Akerson, Secretary to the President, 30 July 1930, Correspondence, 1925-1939, William Anderson Papers, HHPL; CRI \& P Railway's W. E. Babb to Mr. Avery, 30 July 1930, ibid.; "Tomato Festival Opens Shipping Season at West Branch," [West Branch Times, 14 August 1930], Scrapbook 8, 1930-1934, Stratton Papers. 
Carran was becoming distressed and frustrated by the persistent error that she was Hoover's first teacher.

This difference did not keep her from again joining Hoover in his Iowa campaign. In 1931, when Hoover was approaching a tough re-election campaign, Carran, despite her health problems, ${ }^{40}$ wrote that she hoped "to entirely recover and be able to do my share in the coming campaign." In early 1932 she wrote that she was "just as enthusiastic in the campaign as I was four years ago. I am not entirely recovered \& am lame but otherwise I am able and will do all I can for the nomination and election of President Hoover." She received copies of Hoover's speeches, and her offer to be in the political limelight once again to support Hoover was accepted. ${ }^{41}$ The Republican Party in Chicago invited the 78-year-old disabled widow to attend their dinner on the opening day of their presidential nominating convention there in August. She declined for health reasons and wrote to Hoover asking him to stop to see her on his way to open his 1932 campaign in Des Moines. Hoover replied that he could not do so, but asked her to join his special presidential train at West Liberty. She did not think that she was able to make that grueling overnight roundtrip of almost 24 hours, even though she said that she very much wanted to see Hoover again after threeand-a-half years. With much encouragement from leading state and local Republicans, she finally decided that she could do it. ${ }^{42}$

40. Hoover to Carran, 5 December 1930, Scrapbook, 1923-1932, Carran Papers. Her obituary reported that she had been in bad health for three-and-a-half years before she died in mid-May 1934, which also dated her illness from the fall of 1930. [West Branch Times, 24 May 1934], Scrapbook, 1930-1964, Carran Papers.

41. Mrs. J. K. Carran to Mrs. Hoover, undated ("ackd 2/6/31"), Personal Correspondence, 1929-1933, Mollie Brown Carran, Lou Henry Hoover Papers; Mollie B. Carran to President and Mrs. Hoover, 1 March 1932, ibid. Carran continued her interest in Hoover after his electoral defeat and asked for copies of speeches he delivered while he was still president. Mollie Carran to Mildred Hall, White House, 1 November 1932, ibid.; Eleanor Carran [Mollie Brown Carran's daughter] to Mildred Hall, 19 February 1933, ibid.

42. "West Branch Woman Invited to Dinner of G.O.P. in Chicago," [14 June 1932], Scrapbook, 1930-1964, Carran Papers; "A Letter from the President," [3? October 1932], ibid.; Carran to Mrs. Marian MacGregor, 17 October 1932, ibid.; "Hoover's Teacher . . . .," [Iowa City Press-Citizen, early October 1932], ibid.; Stratton, Home Town, 143-44; "Mollie Carran Journal and Souvenir Booklet," 10 September 1932, Acc. 394/3, ibid. 


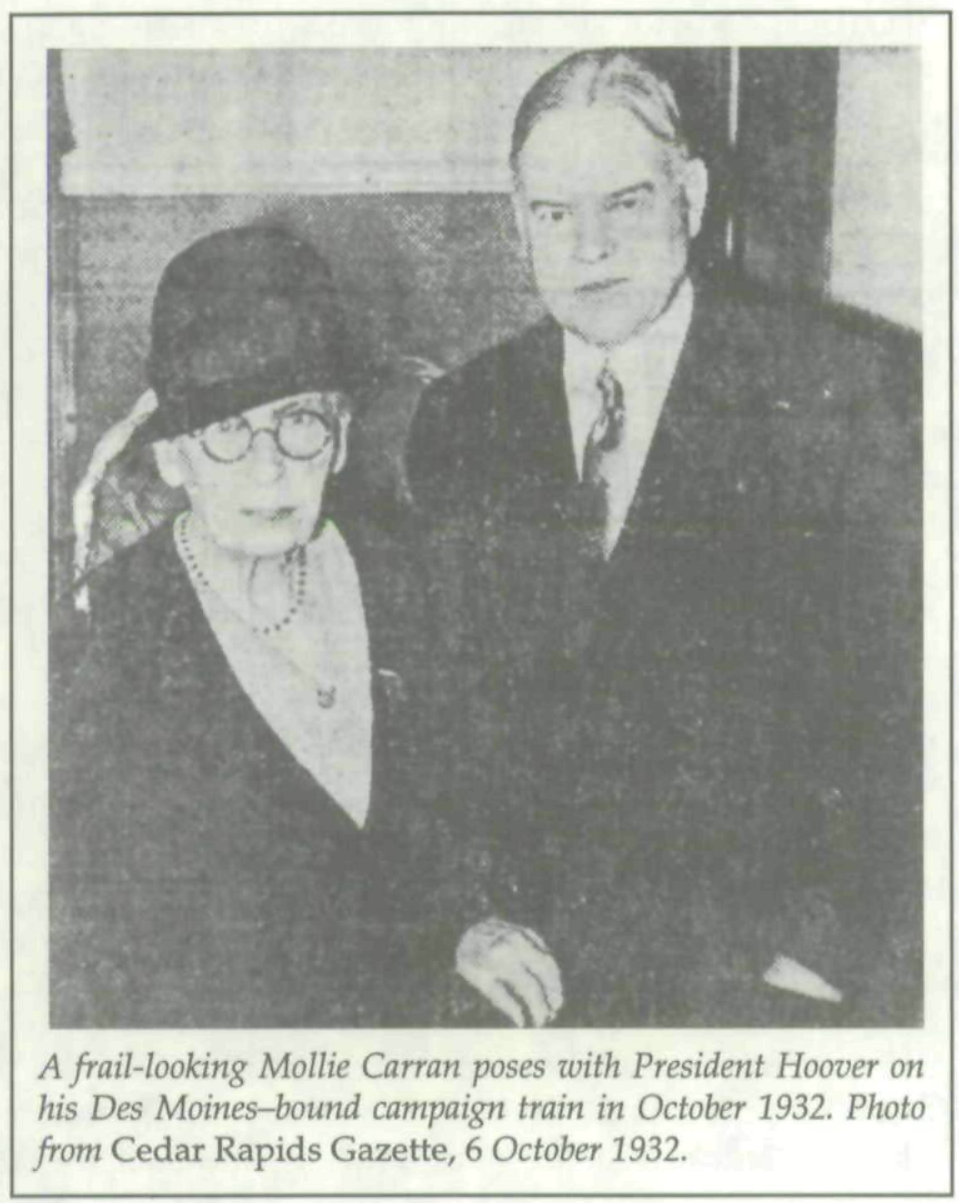

After Hoover called her the "teacher of my first schooling" at West Liberty in 1932, Carran appeared to be angry. At the next short campaign stop in Iowa City, Carran complained explicitly about being called "the first teacher." She was quoted as saying, "Mrs. Sunier of Iowa City was Bertie's first teacher. I was his third and last teacher. ... I cannot understand why people insist on calling me 'the first teacher.' I have corrected that times without number; but some folks insist upon having their own way whether they are right or not. ${ }^{\prime 3}$ Judging by the timing of her outburst, just after Hoover seemed to call her that, Carran

43. Christian Science Monitor, 4 October 1932. 
may have included Hoover among those who insisted on having their own way in calling her his first teacher. If that circumstantial judgment is correct, then Carran believed either that Hoover was misleading the press or that he himself was calling her his first teacher. Before his speech in Des Moines that evening, Hoover surely heard about Carran's denial, as it was in the newspaper that day. That evening he did not mention her name when he spoke of his early education in West Branch, even though she was on the speaker's platform with him. Still, he did nothing then or subsequently to discourage the media's celebration of Carran as his first teacher.

In 1948, at his seventy-fourth birthday party and homecoming to West Branch, Hoover again spoke of Mollie Brown Carran as though she was his first teacher, but avoided explicitly saying so. He recalled the "great lady who first taught me in school and remained my friend during her whole long and useful life, Mrs. Mollie Carran." ${ }^{14}$ Even 25 years after his words and actions had first hinted that Mollie Brown Carran was his first teacher, and as the only survivor of the four persons most involved in that puzzle, including his wife, Hoover did not say explicitly and unequivocally that Mollie Brown was his first teacher.

Nevertheless, in part because he never unambiguously denied the claim either, the error continued to spread, and by the end of the twentieth century it was almost universal. In the late 1990 s, three local residents, who had been about 11 years old when Hoover addressed them in 1923 as students in West Branch, remembered that he had told them that his first teacher was Mollie Brown. ${ }^{45}$ Even Mollie Brown Carran's descendants believed that she was Hoover's first teacher. ${ }^{46}$ The error was so popular for so long that it even found its way into a respected

44. Herbert Hoover, "Homecoming Address by Mr. Hoover at 74th Birthday Reception in West Branch, Iowa," 10 August 1948, Public Statements, vol. 82 no. 3083:1; also in Annals of Iowa 38 (1966), 552. The ambiguity arises here because Hoover could have been comparing two stages of his association with Mollie Brown Carran: first she was his teacher and later she was his friend.

45. Minard Thomas and Floyd Fawcett, interviews by author, 9 August 1999, West Branch; William Edgerton, interview by author, 8 March 2001, West Branch.

46. Mollie Brown Carran's grandson, Robert McNeil Carran, reported that his family had always said that she was Hoover's first teacher. Interview by author, 31 October 1999, Iowa City. 
scholarly work. ${ }^{47}$ After Carran's death in 1934, the only resistance to the error came from the school board and its history adviser, Maud Stratton. ${ }^{48}$ Perhaps political and psychological factors can help us understand why Hoover never disclaimed the error but appeared to encourage it.

THE CLAIM that Hoover attended a one-room school first arose from a newspaper article a generation after his 1923 visit to West Branch. In 1923 he had said that the "little white schoolhouse he attended under Miss Brown seemed bigger to him then than the present modern structure. ${ }^{\prime 49}$ Many of the adults at that speech who would have attended the same building knew it as the two-story school built in 1867 and expanded in $1877 .{ }^{50}$ It was destroyed by fire in 1892 . In 1923 the youngest of those who had started in the 1877 enlarged school building would have been about 36 years old and could not have mistaken Hoover's description of it for the 1853 one-room school. He called his old schoolhouse "little" only in comparison with the newest building dating from 1920, but remembered that two-story building as so large that it seemed "bigger" than the modern building. In 1923 Hoover may not have even known about the 1853 oneroom school; at least he made no reference to it, even though it stood less than 600 feet from where he spoke. In 1937 and again in 1948 local journalist-historian Maud Stratton wrote about Hoover's first schoolhouse in ways that gave no hint of the 1954 claim for that 1853 school building. She wrote that by 1929 "the old white schoolhouse had long since disappeared." "The schoolhouse built in $1870 \ldots$ was the building in which the boy Herbert Hoover received his early education. ${ }^{\prime 51}$

In 1954 a convergence of geography, construction, building name, century anniversary, a weakening of "living memory," and newspaper mistakes led to the claim that Hoover had at-

47. Burner, Hoover, 206. David Burner was selected as the author of the article on Hoover in the Encyclopedia of American Biography (New York, 1974), 534-36.

48. West Branch Board of Education, School (1935).

49. "West Branch Welcomes Native Son."

50. Wickersham, "School History," Scrapbook 3, Stratton Papers.

51. Iowa City Press-Citizen, [1937], ibid.; Stratton, Home Town, 134. 
tended the 1853 one-room schoolhouse. By then, the weakening of the "living memory" about the 1877 school building was considerable; 30 years after 1923 the youngest of those who had started school in that 1877 building would have been about 68 years old. West Branch's relationship to Hoover's early years in the community had entered a "twilight zone that lies between living memory and written history," a breeding place of error. ${ }^{52}$

In 1953, just one hundred years after the town's one-room school had been built, the West Branch school board began building a new elementary school just 200 feet south of the 1853 building. In December of that year Hoover agreed to have the new elementary school named after him. ${ }^{53}$ In January a newspaper article at first tentatively described the 1853 schoolhouse as "the one-room structure in which Herbert Hoover is said to have begun his formal education" (emphasis added). This same vague expression was used in the caption of the accompanying picture, but these cautious statements were then overpowered by two consecutive sentences seeming to say that Hoover had attended that one-room school: "The late Mrs. Stephen Sunier recalled . . . being Herbert Hoover's first teacher. The little one room schoolhouse was later moved to the corner of Oliphant and Orange streets, where it still stands." These seemingly related sentences invited readers to jump to the conclusion that Herbert Hoover and his first teacher had been together in that one-room school. Indeed, that conclusion was trumpeted in the article's headline: "New School Next to Building Where Hoover First Studied." ${ }^{54}$

This error spread quickly. The next day the Cedar Rapids Gazette followed with an article that spoke of the building under construction as standing "side by side with the little building in which the former President of the United States began his for-

52. Michael Kammen, Mystic Chords of Memory: The Transformation of Tradition in American Culture (New York, 1991), 31, referring to C. Van Woodward, The Strange Career of Jim Crow (New York, 1955), viii. The school Hoover attended burned in 1892, so the last students to start there were born about 1886.

53. "Board Names New School," Scrapbook 5, 1940-1957, Stratton Papers.

54. "New School Next to Building Where Hoover First Studied," Iowa City Press-Citizen, 16 January 1954, ibid. 
mal education. ${ }^{\prime 55}$ Another large eastern Iowa newspaper later joined the promoters of this new claim. ${ }^{56}$ Even the West Branch Board of Education, which two decades earlier had rejected the claim that Mollie Brown was Hoover's first teacher, immediately accepted the claim that he had attended a one-room school. Its 1954 updating of its history booklet bragged, "From the oneroom building where he first attended school Mr. Hoover's education continued in an unparalleled career all over the world. ${ }^{157}$ In August 1954, when Hoover, now 80 years old, dedicated the new elementary building named after him, he surely knew about this new claim, but by his silence he let it stand. ${ }^{58}$

POLITICAL CONSIDERATIONS may have been a factor in the emergence and spread of the error about Hoover's first teacher. Hoover stood to benefit from the error, which was accepted because, like the old errors about early American heroic figures, it "turned out to be more attractive than [the] truth." But the error may not only have been passively accepted; it may have been actively promoted as a political strategy to enhance Hoover's appeal as a presidential candidate.

It should not be surprising that there would be an effort to polish Hoover's public image. As one of his biographers put it, his 1928 campaign was "to a considerable extent orchestrated by an expert at public relations-Herbert Hoover. ${ }^{\prime \prime 0}$ Events in

55. "Newest, Oldest Schools Stand Together," Cedar Rapids Gazette, 17 January 1954, ibid.

56. Ia-Ill Times, 25 July 1954, ibid.

57. West Branch Board of Education, Schools (1954), 18; the error was repeated in the updates in 1965 (pp. 25-26) and 1980 (p. 18).

58. Herbert Hoover, "The Protection of Freedom," 10 August 1954, Public Statements, vol. 88 , no. 3532 . Hoover was not scheduled to give a formal speech during the morning dedication of the school, but one newspaper reported that he recalled "the memory of his own childhood teachers through the age of 10 in West Branch." The newspaper account recorded no specific names or buildings, however. "Dedicates School Named in His Honor," [Iowa City PressCitizen, August 1954], West Branch Hoover-related clippings 1954, Lawrence Rummels, Cedar County Collections, HHPL; "[School Dedication] Program," ibid.

59. Kammen, Mystic Chords of Memory, 26.

60. Burner, Hoover, 197. 
Hoover's earlier life suggest precedents for how the false headline could have come about in 1928. In college, Hoover liked to operate behind the scenes as a "wire-puller" and by "covert selfassertion." Ever thereafter he had "a keen sense of publicity" and was very skillful in using the press to promote his ideas and to put pressure on others, including effective leaking of news stories. Many of Hoover's best friends were newspapermen who were eager to help him. The most likely of these, one who had the skill and the will to manipulate the press, was prominent newspaperman and writer Will Irwin, Hoover's college and lifelong friend. Irwin was part of a group of seven leading journalists and editors organized in 1927 "to mold public opinion behind" Hoover. ${ }^{61}$

The person most likely to be involved in any covert campaign to promote Carran as Hoover's first teacher, however, had close connections to Carran through her family background in West Branch. Marian Madsen MacGregor was the founder and head of the national West Branch Hoover for President Club, working out of Republican headquarters in Chicago. ${ }^{62}$ A letter that Carran wrote to MacGregor describing her trip on Hoover's train to Des Moines in 1932 was held for two weeks and then published a week before the election with the gratuitous headline: "Letter by Hoover's First Teacher." ${ }^{\prime \prime 3}$ Four years earlier, two days after the 1928 election, an Associated Press release, headed "'Hoover's First Teacher Happy; Mrs. Carran Congratulates 'Bert,'" described MacGregor as the vice-chairman of the women's department of the Republican national committee finance work. ${ }^{64}$ The circumstantial evidence that MacGregor was associated with two "First Teacher" articles, the very first of the kind in Hoover's 1928 campaign and then again during his 1932 cam-

61. Nash, Hoover the Engineer, 39, 290, 430, 477, 512 (original emphasis), 542-58 (quote from 555); Who's Who in America (1928-29), s.v. "Irwin, William Henry"; George H. Nash, The Life of Herbert Hoover: The Humanitarian, 1914-1917 (New York, 1996), 377.

62. Stratton, Home Town, 119.

63. Carran to Mrs. Marian MacGregor, 17 October 1932, [published 31 October 1932], Scrapbook, 1930-1964, Carran Papers.

64. "Hoover's First Teacher Happy"; "Former West Branch Woman Prominent at Republican Convention," [June 1928], Scrapbook, 1914-1928, Carran Papers. 
paign, may suggest that she was covertly promoting Carran as Hoover's first teacher for campaign purposes.

Even Hoover's own first singling out of Carran shows signs of political calculation. Hoover as an adult had not made any effort to see Carran until he began seriously pursuing the presidency in $1923 .{ }^{65}$ He had visited West Branch in 1897, in 1899, and again about 1915 , but did not call on his old teacher. ${ }^{66}$ Furthermore, from 1902 to 1916 he made at least a dozen other round trips, usually with his family, by ship and cross-country train from his office in London, England, to California, but never made a small schedule adjustment to stop in West Branch to see his old teacher. ${ }^{67}$

The timing of Hoover's first adult visit to Carran, a public visit made only when he was planning to run for president and after ignoring so many earlier opportunities to visit her, was just the first step in what appears to be the political aspect of his renewed association with her. On his 1928 presidential campaign visit he again gave her special treatment. By then another teacher had claimed to be Hoover's first teacher, but he had already chosen the one who most appealed to him personally and who would be more helpful to his political career.

Elizabeth Chandler Sunier encouraged the belief that she was Hoover's first teacher, but never explicitly said so. She taught in West Branch for only one year, 1880-81, when Hoover was her pupil. ${ }^{68}$ By 1928 she had been gone from West Branch for almost

65. In 1920 Hoover entered the Republican Party's presidential primaries in California and some other states, but did not mount a full campaign. When Warren G. Harding became the Republican nominee, Hoover loyally supported him. In 1924 Hoover was not a candidate, even though he took an initial step in visiting West Branch in April 1923. Calvin Coolidge did not run for re-election in 1928, and Hoover had little opposition for the Republican Party's nomination.

66. Carran wrote that she first saw Hoover again in 1923, and 1928 was "my second contact with him as a man." Carran, "Hoover: The Boy, the Man, the President"; Nash, Hoover the Engineer, 51. Hoover's sons first saw West Branch in 1928, when he was a presidential candidate and they were aged 23 and 17. This also seems to have been Lou Henry Hoover's first look at West Branch. Stratton, Home Town, 128.

67. Nash, Hoover the Engineer, 51, 605n, 86-87, 503, 560.

68. "Hoover Given Right Start." 
a half-century and apparently had few if any local ties and no political influence there.

Sunier's early association with her now-famous pupil, as well as statements she made during his presidential campaign, made her unappealing to Hoover personally as well as a political liability. Her greatest personal disadvantage was that she ended any possible nostalgic ties with presidential candidate Hoover by publicly criticizing his mother. Sunier implied that Hoover's widowed mother had put her own non-traditional religious work ahead of his education. In a 1928 newspaper interview, Sunier said, "He did not come until about the second week after school began, probably because his mother had been away preaching." Preachers were a novelty among area Quakers, and women preachers were even more so. Sunier said she herself was "brought up" a Quaker and apparently was part of the group that in 1879 disapproved of recent changes in Quaker worship. ${ }^{69}$ Sunier felt strongly enough about this to refer to it nearly 50 years later.

Even if she had not expressed that feeling to young Hoover, he may have sensed her disapproval of his mother for preaching and for neglect of her children. Whether or not Hoover felt neglected by his mother, he surely must have reacted negatively to Sunier's later implied criticism of his mother for putting her work ahead of care for him. Furthermore, Sunier publicly stated her mixed feelings about her former pupil just before his presidential campaign visit to West Branch in 1928. She was quoted as saying, "Bertie sat in the southwest corner of the room. He never looked at me but that he smiled.... Bertie was a smiling boy and good-natured, but he had a reserve about him that was puzzling..... You didn't have to tell that boy to study. Oh, I liked him and he liked me.."10 Her statement revealed that Bertie and

69. Ibid.; Nash, Hoover the Engineer, 9-10. Hoover's mother was among those promoting changes in the Quaker form of worship, such as hymn singing and programmed services with certified preachers. She continued such activities after she became a widow when Hoover was in second grade. About a year later she was recognized as a recorded preacher.

70. "Hoover Given Right Start." Sunier may have looked down on working people like Hoover's family. She claimed that there were five generations of teachers in her family, including two college presidents, and she even cited a family tradition that Bishop Swithin, tutor of William the Conqueror (of Eng- 
she got along well, but that she felt that something created a certain distance between them.

By contrast, when Hoover began seeking the presidency, Mollie Brown Carran admired him very much and could bring him political benefits. Mollie Brown Carran's words carried weight because she had long and strong ties locally. She and her family had moved from Pennsylvania to a farm north of West Branch in 1864 when she was about ten years old. They were members of the rural Fairview Presbyterian congregation; when that church closed in about 1915, she and her husband remained "zealous Presbyterians" even as they attended the Methodist church in West Branch. Mollie Brown had started teaching school in nearby Downey at the age of 16 and taught in rural schools before teaching in West Branch from 1883 until the spring of 1885, when she married a local farmer, John Carran, and, by the custom of the time, gave up teaching.

She did not drop out of public life, however. In 1901 a Cedar County history described Mollie Brown Carran as "one of the best known women in Cedar County." In 1928 a Chicago reporter who did a four-part series on Hoover's background wrote, "What Mollie Brown says in the little town of Hoover's birth goes. She has been a factor to be reckoned with in West Branch for fifty years, and in the history of Cedar county her name is blazoned high." The reporter's list of her successful betterment projects supported that claim. ${ }^{72}$

That Mollie Brown Carran was not a Quaker probably increased her political weight. There were not many Quaker voters

land in 1066), was connected with her family. She was a member of the Daughters of the American Revolution and in 1929 attended their convention in Washington, DC, where she and her daughter "were received by the President and assisted Mrs. Hoover during the reception to the convention." Replying to a question, she said that she had followed Hoover's public career through the newspapers but "didn't pester him with letters." She would not go to Des Moines for Hoover's re-election speech there, but would like to go to Washington about a month after the presidential inauguration "to see the cherry blossoms, and, of course, Bertie." Christian Science Monitor, 4 October 1932.

71. Mollie Brown Carran's background is described in her obituaries and in newspaper clippings about her former teacher, Mrs. Moore. [West Branch Times, 24 May 1934], Scrapbook, 1930-1964, Carran Papers; Cedar Rapids Gazette, [16 May 1934], ibid.; [West Branch Times, 28 November 1929], ibid.

72. History of Cedar County, 2:219; "Carran Keeps Chronicle." 
on the national level, and her mainstream Protestant ties would appeal to a large block of voters. Nor was Carran's religion a problem for Hoover, as it appears that he had no strong religious denominational convictions or prejudices. ${ }^{73}$

Of course, like almost everyone else in the West Branch area, Carran was a strong Republican. Even before he was nominated, she wrote a laudatory article about him in the school section of the local newspaper. There she named Hoover's basic characteristics as putting his whole heart into whatever he was doing, keeping still when he had nothing to say, and gratitude, such as to "an aunt who befriended him when he was a lonely, homeless boy. ${ }^{\prime \prime 4}$ Herbert Hoover's political career could benefit from being associated with such a loyal and locally respected and influential person as Mollie Brown Carran.

Associating Carran's name with his own had the potential to help Hoover nationally to some degree in several ways. Not least was the emotional appeal that could be wrung from the connection. Starting his campaign speech in West Branch in 1928 with his nostalgic memories about how Mollie Brown had offered to adopt him, Hoover expressed his gratitude to her and surely left many local and radio listeners with the doubly appealing emotional image of a grateful orphan. ${ }^{75}$

No less important, Carran represented the new women voters taking part in federal elections for just the third time in 1928; also, about 25 percent of women voters would be eligible to vote for the first time. Hoover worked hard for those votes, especially on the big issue of prohibition. The Woman's Christian Temperance Union publicly supported Hoover. Hoover summed up his appeal to women the night before Election Day in his national

73. There is no record that Hoover and his family attended any church services or Quaker meetings during the more than dozen years they lived in London. Hoover had agreed to his bride's wish that their marriage ceremony be performed at her Episcopalian family home by a Catholic priest. Nash, Hoover the Engineer, 499-500, 86-87; Burner, Hoover, 32.

74. "'Bertie' Hoover as His West Branch Teacher Knew Him"; Mollie Brown Carran, "Herbert Hoover, Secretary of Commerce," Purple and White [in West Branch Times], May 1928.

75. Hoover, "Childhood Recollections," 21 August 1928, Public Statements, vol. 36, no. 885:1; also in Hoover, Boyhood in Iowa, 30-31; and Stratton, Home Town, 125, 127-28. 
radio speech, which included praise for women's moral and spiritual concerns and asked them to exercise their right to vote. In his campaign's appeal for women's votes, Hoover's praise for his own teacher, a member of a profession composed at that time mostly of women, would get the attention of a lot of women voters. After the election, the Christian Science Monitor confirmed that Hoover's victory was due in large part to women's votes. ${ }^{76}$

Carran's role as Hoover's early teacher in a small town in the Midwest could also help to overcome the view that Hoover was not a real American. He had lived most of his adult life abroad, and there were rumors that while living in London he had considered becoming a British citizen. ${ }^{7}$ Hoover's association with Mollie Brown Carran, a down-to-earth midwestern schoolteacher, could heip to dispel such concerns about his patriotism.

Mollie Brown Carran also had strong ties to what were commonly seen in the 1920 s as traditional values. That could help Hoover combat a reputation he had acquired as U.S. Food Administrator during World War I, "when a traditionally decentralized and libertarian society made a staggering leap toward a centrally managed economy. Never before had the federal government regulated the lives of its citizens, even unto their eating habits, as it proceeded to do after April 1917. . . . Of this convulsive wave of interventionism, Hoover was both an agent and a catalyst." ${ }^{\prime 78}$ Linking himself to the images evoked by his early schooling under Mollie Brown Carran in Iowa might help to associate him with so-called traditional American values.

76. Christian Science Monitor, 16-18, 21, 23, and 25 August and 7 November 1928. 77. George H. Nash, The Life of Herbert Hoover: The Master of Emergencies, 19171918 (New York, 1996), 74; New York Times, 17 October and 9 December 1928. During this controversy, a Republican official published a 1916 memorandum by an eminent Democrat to President Wilson recommending Hoover's appointment to a top position in the U.S. State Department. Part of that memorandum reported that the British government had suggested to Hoover that he become a British subject so he could be appointed to a top executive post, with the prospect of a later aristocratic title. Hoover's reported answer was that he would help Britain any way he could during the war, but would never give up his American citizenship. "A Memorandum on Herbert Hoover," Unidentified, Carran Papers; an earlier report of this question about his citizenship was reprinted in the West Branch Times, 5 July 1928, from the Eagle Grove [Iowa] Eagle, Clippings, 1925-1928, William B. Anderson Papers, HHPL.

78. Nash, Hoover the Master, $x$. 
A number of other more important factors combined to ensure that Hoover's chances of victory in the 1928 election were good: the economy (except for the agricultural sector) was strong, and he was campaigning in the shadow of a successful Republican president, for example. But good politicians seize every opportunity to strengthen their appeal to voters. Hoover's association with Mollie Brown Carran was surely not a deciding factor in his landslide victory in the 1928 presidential election, but it could have helped, especially by adding more personal appeal to someone who was often seen as a "cold fish."

IT MAY SEEM STRANGE that there was no direct challenge from the local community to the claim that Mollie Brown Carran was Herbert Hoover's first teacher, for local people knew that she was his fourth-grade teacher. The explanation may lie in a sociological study that described West Branch during Hoover's presidential campaign in 1928. It concluded, "The community reached its height of unity in thought and action during this period. Every inhabitant wished to cooperate in the activities, to be on the inside, to feel that he was a part. Group differences were at an absolute minimum. ${ }^{\prime 79}$ In such an atmosphere, few would want to do anything that might disturb the community's unity, such as questioning that Mollie Brown Carran had been Hoover's first teacher. Most people with local pride or commercial interests must have valued the benefits of any publicity connecting their town with Hoover; if someone in the national press wanted Hoover's first teacher to be the one who still lived in the town, the local people and press would not dispute it. As it had been for Hoover himself, so also for the community was the error more attractive than the truth. ${ }^{80}$

In the early 1930s Hoover's reputation and the community's spirit had been splintered by the Great Depression and Hoover's

79. Lois [Huldah] Hollingsworth, "West Branch: A Study of a Rural Community" (master's thesis, State University of Iowa, 1933), 49.

80. Kammen, Mystic Chords of Memory, 26. Since at least 1911 the local newspaper had a booster policy, according to a eulogy for the longtime owner and editor. "F. E. Corbin [Sr.], Publisher of West Branch Times, Mourned by Associates of Nearly Three Decades," West Branch Times, 9 May 1940, Acc. 554/2, Stratton Papers. 


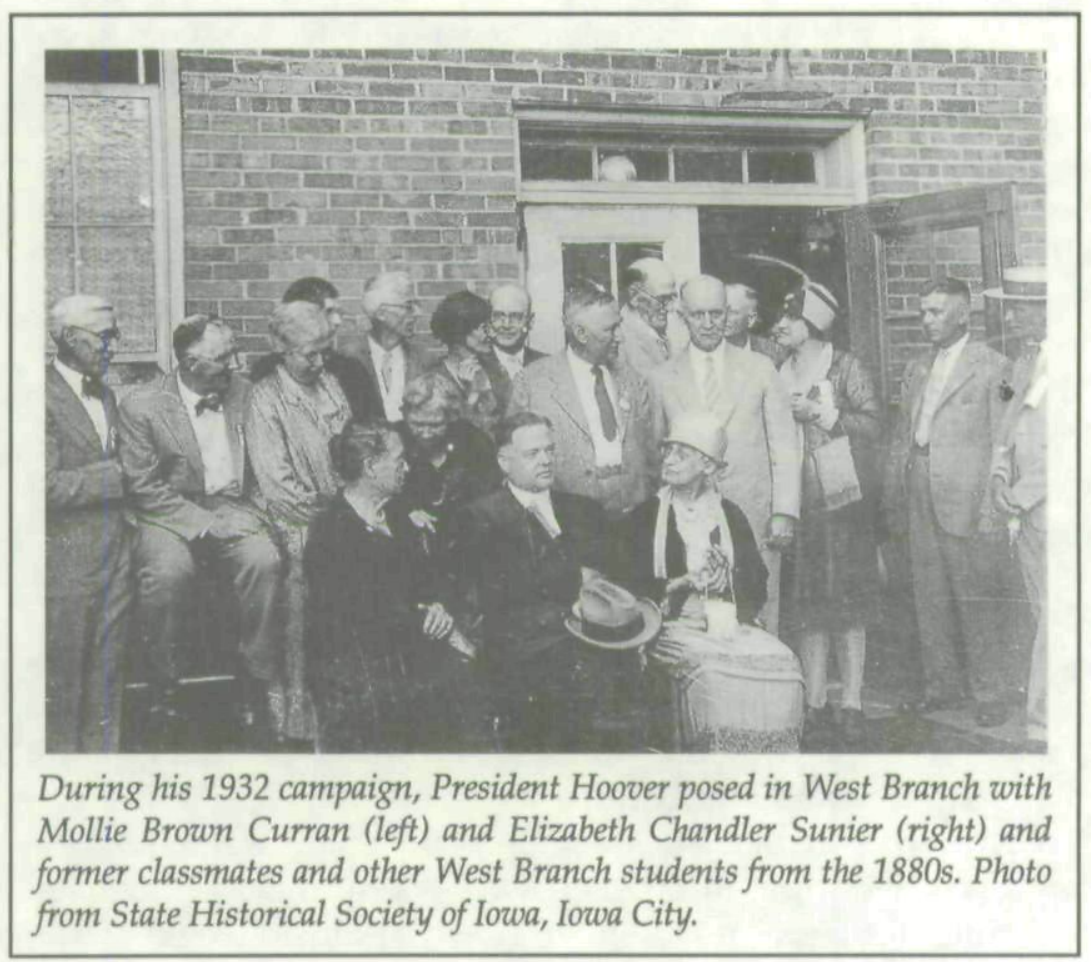

failed re-election bid. Local journalist-historian Maud Stratton, looking back from 1948, described the bad times as the election of 1932 approached. Local residents "had no illusions, and nowhere was the audience more critical as campaign speeches poured over the [radio] air. The Quaker sense of fairness made certain that faults would be detected and discussed." Stratton also reported that Hoover won three-quarters of the West Branch vote even in 1932, but the magic and the "illusions" were gone. A graduate student writing a sociological thesis in 1933 described the mood this way: "Hoover's failure to be reelected in 1932, the long economic depression which the farmer had suffered, and finally the failure of all the banks in the community on January first, 1933, furnished a focus for the growing discontent and lack of confidence in the community. . . . The same mass movement [to support Hoover] which had held the community together was now forcing it into disintegration. ${ }^{181}$

81. Stratton, Home Town, 146-47; Hollingsworth, "West Branch," 50, 66. 
By 1948, when Hoover made his last public statement about Mollie Brown Carran, his wife and his two leading former teachers had died. In addition, other conditions in Hoover's career and in West Branch had changed dramatically. Hoover's reputation was rebounding from the association of his presidency with inadequate efforts to end the Great Depression. During and after World War II Hoover again headed efforts to alleviate world food problems, and in 1947 he had begun the first of his two "Hoover Commissions" to help both President Truman and President Eisenhower reorganize the executive branch. ${ }^{82}$

By 1948, West Branch, too, was recovering from setbacks even as it dealt with the changes that recovery wrought. Major nationwide economic and social changes during and after World War II were challenging the traditional ideas and values of big cities and small towns, perhaps especially in a town such as West Branch. ${ }^{83}$ Nevertheless, many West Branch people did not think, or perhaps did not want to think, that things were changing. Concluding her history of West Branch with this immediate postwar period, Maud Stratton emphasized that the town was returning to familiar ways: "Returning service men went into business, and the town slowly resumed its old tempo -day by day living, hoping for the best, still working in unison." ${ }^{184}$ Eight community leaders echoed that view. ${ }^{85}$ Nevertheless, in West Branch important changes in values and ways of thinking threatened the old ones. New residents, both commuters and those employed locally, were bringing wider outlooks and cultural traditions. Prior to the war, West Branch had been mostly an isolated rural town whose basic ethnic and religious traditions were different from those in surrounding areas and towns. Two striking examples of value changes in West Branch were that during World War II many schoolteachers did not fulfill their original contracts, and some returning service-

82. Eugene Lyons, Herbert Hoover: A Biography (Garden City, NY, 1948), 409-17. 83. Noel P. Gist and Sylvia Fleis Fava, Urban Society, 6th ed. (New York, 1974), 294-95.

84. Stratton, Home Town, 169-70.

85. Terry T. Alliband, "Suburbanization and Survival: An Anthropological Study of West Branch, Iowa" (Ph.D. diss., University of Iowa, 1974), 53-54. 
men from the majority Protestant families married local Catholic women and became Catholics. ${ }^{86}$

Under such conditions, many in the community were comfortable being reminded of their ties to the past, especially their previously happy association with Hoover. West Branch's most respected journalist-historian described the symbiosis of community traditions and a resurgent national leader this way: "In short, there was an ideal to cherish, to be the kind of community which could produce the right kind of presidential material, that neither might have any apologies for the other." ${ }^{87} \mathrm{De}-$ spite their emphasis on progress, Americans after World War II, and especially some in West Branch, had strong urges to return to the time before the war and the Great Depression, to "a simpler world in which life was easier to live and to understand." ${ }^{188}$

The postwar renewal of the town's traditional summer "Community Day" was followed by the wider celebration of Hoover's seventy-fourth birthday in 1948, which provided an opportunity for both the community and the statesman to reaffirm traditional values. In his speech there Hoover emphasized the importance of religion, family, individual self-sufficiency, hard work, and the meaning of America, which he defined as "freedom of mind and spirit in man." Hoover's claim in that speech that Mollie Brown was his early teacher and instructor in the meaning of Americanism was a clear tie to the old times. ${ }^{89}$

This same general postwar tendency to respect the past was the setting for the birth of the error that Hoover had attended a one-room school. As a scholar perceived through the eyes of his West Branch interviewees, 1948 was the beginning of more than a decade of "relative harmony, steady growth, and a resurgence of community confidence ... much as it had been in the years before World War II." ${ }^{\prime 90}$ In this "twilight zone ... between living

86. More details are in the author's "The West Branch, Iowa Area: Schools, Catholics, Immigrants-Toward a Balanced History," unpublished manuscript in the author's possession.

87. Stratton, Home Town, 131.

88. Kammen, Mystic Chords, 533, quoting a 1939 New York Times editorial about the Gay Nineties.

89. Hoover, "Homecoming Address."

90. Alliband, "Anthropological Study of West Branch," 53-54. 
memory and written history" multiple coincidences made it irresistible to accept in 1954 that ex-president Hoover had attended the first school in West Branch, built a century earlier. The one-room school error apparently arose from journalistic carelessness or boosterism, making it unlikely that Hoover played any active part in the rise or spread of that claim.

The absence of his involvement with the one-room school claim contrasts with his repeated hints over a 25 -year period that Mollie Brown Carran was his first teacher. His actions in West Branch in 1923 foreshadowed it, and after his election in 1928 it was reported as fact in many newspaper articles, possibly as a result of some clandestine promotion of that error on his behalf. Although Hoover stood to benefit politically from the claim, that may not be the whole story, or even the most compelling reason why Hoover was susceptible to the error that Mollie Brown Carran was his first teacher.

THE PSYCHOLOGICAL BENEFITS for Hoover of the firstteacher claim may have been more important to him, at least later in his life, than the political benefits. In 1948, when he last publicly spoke of Mollie Brown Carran, Hoover was 74 years old and could derive no direct political benefit from the error. Besides needing to be consistent with his earlier statements about Carran, it may be that his association with her had become part of his own personal image of himself. A review of some emotional crises in his early life may help us consider how much Hoover may have needed the feeling of security provided by his tie to Mollie Brown.

After his father died, six-year-old Hoover was dependent upon his mother for affection and emotional support. He may have felt neglected by his mother, as he later hinted. The only statements in Hoover's memoirs about his mother are rather impersonal and ambiguous ones that credit her with only two of the more than three years that she was the sole parent. Contrasting his memories of his father and mother, Hoover noted,

My recollections of my mother are more vivid and are chiefly of a sweet-faced woman who for two years kept the little family of four together.... Since my mother had been educated above most 
women in those days - as a school-teacher-she was in demand as a speaker at Quaker meetings. She also took a considerable part in the then vigorous prohibition campaigns. On one occasion, I was parked for the day at the polls, where women were massed in an effort to make the men vote themselves dry. ${ }^{91}$

Hoover's mother did worry about neglecting her children as she concentrated on what she considered her most important work-preaching-as she wrote to her sister Agness: "I just keep myself ready first for service for my master-then to work at whatever I can to earn a little to add to our living and then the care of my little ones every day is full and some times the nights." Earlier, she wrote to Agness and their mother, "I will try to do what I can and not neglect the children." Just after Hoover returned from Indian Territory, his mother left for the Friends Yearly Meeting in Kansas City and later assured her sister that while she was away, "The children were well and well cared for-I hired Uncle Will. Miles to board Berttie. ${ }^{\prime \prime 2}$

Scholars have described Hoover as "thin-skinned" about criticism of his policies, suggesting that this "excessive sensitivity to slights" may have resulted from his sense of being "abandoned by his parents and the absence of empathetic understanding from those who raised him." A recent biographer noted of Hoover's whole childhood, "He wrote a bit resentfully of being handed from one family of relatives to another. ... Much of his career would be occupied with getting power and control for himself, and with creating order and stability around him." ${ }^{\prime 93}$

Hoover may indeed have felt like a burden to his relatives. During the more than three years that he had only one living parent, he was probably "parked for the day at the polls" by his activist mother more than the once he reported. During the

91. Hoover, Memoirs, 1874-1920, 4-5.

92. Hulda R. Hoover to Sister Agness [Miles], 10 October 1883, Genealogy Series, Hulda Hoover Correspondence, 1861-1883, Hoover Papers, HHPL; Hulda to Mother and Aggie, 15 March 1883, ibid.; Hulda R. Hoover to Sister Agness, 10 October 1883, ibid.

93. Nash, Hoover the Master, 407; David E. Hamilton, From New Day to New Deal: American Farm Policy from Hoover to Roosevelt, 1928-1933 (Chapel Hill, NC, 1991), 28, 40; Kendrick A. Clements, Hoover, Conservation, and Consumerism: Engineering the Good Life (Lawrence, KS, 2000), 18-19, 50, 51, 215-16nn.; Burner, Hoover, 12. 
summer he turned nine years old, he was sent to Indian Territory to stay with an uncle from May to late September, causing him to miss the end of one school year and the beginning of another. Just after he returned from there he was boarded out for probably a week or more to a relative in West Branch. Several months later his mother died, leaving him with no continuing close adult support. After a period of about six months of living with relatives in several different places apart from his older brother and younger sister, Hoover was rescued from academic and probably emotional disaster by Mollie Brown. ${ }^{94}$ After Hoover was elected president, the Associated Press reported on his earlier tribute to Mollie Brown Carran: "'She was the light of my life,' Hoover said, without which he might have drifted a derelict on the boundless sea of obscurity." ${ }^{\prime 95}$

Mollie Brown's offer to adopt Hoover surely meant that she took an intense personal interest in his welfare. Hoover's later language hinted at criticism of his relatives and suggested that he had wanted the adoption efforts of his concerned and sympathetic teacher to succeed: "my school teacher, Mollie Brown ... strove to secure me for adoption. But Mollie was then unmarried, and the others [his relatives] insisted that family experience was the first necessity for my control. ${ }^{\prime \prime 6}$

By that time Hoover was at least two grades behind in his schoolwork, and Mollie Brown, a caring teacher, no doubt saw a student who was still trying but was in danger of becoming discouraged. Even though she did not claim the credit, Carran's description of how Hoover was kept in her classroom leaves little doubt that she was the main force behind the effort to get his school program moving forward again. In that classroom of fourth, fifth, and six graders, Mollie Brown could help him as a student and provide encouragement and emotional support. Two of Hoover's former classmates reported that there was a

94. Hoover's adult writings conveyed no warm feelings about his stay with his Uncle Allan and Aunt Millie Hoover and their son Walter, about his age. Hoover, Memoirs, 1874-1920, 3, 6; Hoover, Boyhood in Iowa, 19-20; Nash, Hoover the Engineer, 11; Will Irwin, foreword to Hoover, Boyhood in Iowa, 7.

95. "275 Iowans Plan to Make Trip," 26 February 1929, Scrapbook, 1929, Carran Papers.

96. Hoover, Memoirs, 1874-1920, 5-6 (emphasis added). 
special bond between Hoover and Mollie Brown. One said, "I think that the one great reason that Herbert Hoover holds Molly [sic] Brown up as the outstanding teacher of his life, is because at the time that she was our teacher his mother died and left him an orphan, and she not only taught him but mothered him also." Another classmate said of Hoover and Mollie Brown, "He wasn't exactly teacher's pet ... [but] there was a bond between them somehow." Carran, however, modestly gave all the credit for Hoover's early personal formation to his mother."

Hoover's world was again turned upside down when toward the end of that full school year with Mollie Brown she married and gave up teaching. Then several months later Hoover was sent to live with an uncle in Oregon, where he did not have a happy life. ${ }^{98}$ Almost 38 years after leaving West Branch, on his fourth visit there as an adult, Hoover renewed his ties with Mollie Brown and brought her gifts. By that time he was planning to run for president, had a wife and family, and had achieved professional, financial, and humanitarian success in Europe. His success was far greater than any of Horatio Alger's popular fictional characters of that time.9. Perhaps by then Hoover felt more secure about his childhood.

97. "Newt Butler Tells"; Fred Albin, reported in "Carran Keeps Chronicle"; [Address to the Quota Club].

98. In 1920 "Harriette [Miles] Odell told Theodore Hoover [Herbert's older brother] that she burned Bert's letters telling of unhappy experiences with Uncle John [in Oregon]." Burner, Hoover, 354n.

99. Horatio Alger Jr.'s books about hard-working boys becoming successful were popular in the 1880 s and 1890 s when Hoover began choosing his own reading and no doubt were included in his wide reading. Hoover explained the limits on his reading matter in West Branch in "An Informal Address" [to the Iowa Club in Washington, DC, 1927], An Iowa Boyhood, 16-17; Christian Science Monitor, 24 October 1932. See also Lyons, Hoover, 12, 14, 20; and Burner, Hoover, 13. By the early 1890 s there were more than 50 Horatio Alger books, many with titles (listed in John Tebbel in From Rags to Riches: Horatio Alger Jr., and the American Dream [New York, 1963], 228-33) that seem to have foreshadowed Hoover's career. Russel Crouse, "Introduction," in Horatio Alger Jr., Struggling Upward and Other Works (New York, 1945), viii-ix. When Hoover was a likely presidential nominee, Carran summarized his life in the school newspaper. The article reads much like an Alger success story except that she could have added that Hoover had a college degree and soon realized that manual labor was not a path to success. Carran, "Herbert Hoover, Secretary of Commerce." Hoover's success was based on education, and his emphasis on the importance of teachers updated the Alger model for the twentieth century. 
In 1923, at his first adult meeting with Mollie Brown Carran, Hoover had given some schoolchildren the impression that she had been his first teacher. By the time he was elected president five years later that hint had grown into a nationwide belief that Hoover seemed to confirm during his 1932 campaign for reelection. In West Branch in 1948, the 74-year-old Hoover, now surviving his wife and both of his prominent early teachers, restated his ambiguous designation of Mollie Brown as his first teacher. By that time, the error could neither benefit nor harm any of them. His 1948 eulogy of Mollie Brown as perhaps his first teacher may have been his way of recognizing her as the teacher who first made a lasting impression on him and put him back on the path of school progress, avoiding drifting "on a boundless sea of obscurity." ${ }^{\prime 100}$ This first in importance no doubt meant more to him than any first in time.

Hoover expressed his gratitude to Carran not only through public statements that may have been designed at least in part for his own benefit, but also through private acts of tangible support that mirrored the support she had provided for him as a child. When Carran had accompanied Hoover on the campaign train from West Liberty to Des Moines in 1932, she had told Hoover about her married son's problem getting a job, and one of Hoover's last acts as president was to favor his favorite teacher by passing over 49 other applicants to appoint her son to a post office job in West Branch at what was a very good salary during the Great Depression. ${ }^{101}$

In late September 1933 Hoover paid what might have appeared to be his first purely personal visit to Carran when the ex-president and his wife stopped in West Branch on their way west after visiting the World's Fair in Chicago. ${ }^{102}$ Shortly after-

100. "275 Iowans Plan to Make Trip."

101. Herbert Hoover, "Executive Order No. 5992," 12 January 1933, Public Papers of Herbert Hoover, 6 vols. (Washington, DC, 1974), 2:1396; see also related Associated Press clippings from 17, 25, and 26 January 1933, Scrapbook, 19301964, Carran Papers.

102. "Mollie Carran Journal and Souvenir Booklet," 28 September 1933; "ExPresident and Mrs. Hoover at West Branch," with a picture of Carran, Lou Henry Hoover, and Arthur Hyde, [West Branch Times, 28 September 1933], Scrapbook 6, 1944-1958, Stratton Papers. 
ward, Carran received a letter from Lou Henry Hoover dated from Des Moines later on the day of that West Branch visit offering to pay her grandson John's expenses to continue as an electrical engineering student at the University of Iowa. The next major event involving the Hoovers and the Carrans was seven months later, when Carran died and the Hoovers sent a large bouquet of flowers to her funeral. ${ }^{103}$

Whether or not Hoover felt any need to repay Carran for answering his call to appear again in public with him in 1932, when she was at an advanced age and with disabilities, he may have sought mostly to ease her mind about her family's economic welfare. Almost as if he really had been adopted by Mollie Brown Carran, Hoover acted somewhat as though her children and grandchildren were his own relatives. ${ }^{104}$

Hoover never sought public credit for his generosity to Carran's family. The way the ambiguity of his public statements about her served his own purposes, however, was not an isolated instance. The advice and warning he gave in 1943 to an engineer friend who was writing his autobiography and asked for more information about Hoover's role in some of their joint financial projects reflects his own approach to writing and speaking about his own life. Write only as a disinterested engineer, Hoover advised, and omit anything we did as financiers or promoters. "You will find that point of view holds public esteem."105 In writing or speaking about his own life, Hoover, on a number of occasions, omitted unpleasant facts or gave interpretations that put events in a more favorable light. He also occasionally took credit for important things done by others. His biographer

103. Mollie B. Carran to Mrs. Hoover, 6 October 1933, Personal Correspondence, 1929-33, Mollie Brown Carran, Lou Henry Hoover Papers; Hoover to Albin, 21 October 1933, Correspondence, 1928-1939, William B. Anderson Papers; Iowa City Press-Citizen, [14 August] 1928, Scrapbook, 1914-1928, Carran Papers; New York Times, 15 August 1928, ibid.; obituary, [West Branch Times, 24 May 1934], Scrapbook, 1930-1964, Carran Papers.

104. President Hoover's appointment of someone to a job as a personal favor was not uncommon in the Civil Service system before 1940. Previously, Hoover had not given money but sometimes made loans to deserving acquaintances he knew were in need, but kept no record of how much, if any, was ever repaid. Nash, Hoover the Engineer, 69-70.

105. Quoted in Nash, Hoover the Engineer, 474. 
could have been covering all such examples when he charitably excused Hoover's downplaying of his role in a failed company by writing, "Perhaps he did not care to remember." ${ }^{106}$

On the other hand, Hoover did want to remember, and he wanted the public to accept, that Mollie Brown Carran was his most important teacher. From the available evidence, it is difficult to gauge the relative importance of emotion and calculation in Hoover's association with the first-teacher error. Other factors no doubt also played a part, but these two appear to be dominant, even though they may have switched places during different stages of Hoover's life.

The reasons for this puzzle about Hoover's first teacher are probably somewhat similar to the reasons behind three other errors he made relating to his early schooling: the year he left West Branch, his age then, and his school grade at that time. He repeatedly said that he left when he was ten years old, which dovetails with his indirect statements that this would have been in 1884, and seems related to his ambiguous statement that he left with a "certificate of the fourth or fifth grade of higher learning. ${ }^{\prime 107}$ If indeed he had finished grade five at age ten by the fall of 1884, he would have had a normal progression of one grade per school year.

These three mutually supporting errors of age, year, and school grade came directly from Hoover's own statements, so we may rule out any part played by newspaper incompetence or manipulation by supporters. The simplest and least disturbing explanation is that the very sharp and detail-oriented adult Hoover simply miscalculated the age at which he left West Branch, and then adjusted the year to fit that. But even in that case, mixed motives may have been at work. Since the original source of the errors seems to be early recollections that were intended for his two sons and not for publication, Hoover's goal

106. Nash, Hoover the Engineer, 453; Nash, Hoover the Humanitarian, 13, 16, 32, 264, 268, 299; Nash, Hoover the Master, 425, 517n, 636n.

107. In all of his major speeches to Iowans from 1927 to 1962 and in his memoirs, Hoover either said he left West Branch at the age of ten, or named years of absence that placed his departure in 1884. He mentioned his "certificate" in Herbert Hoover, "A Proposal for Greater Safety for America," 10 August 1962, Public Statements, vol. 96, no. 4230:10. 
was undoubtedly to present a certain image of himself that would be of greater importance than the accuracy of any detail. ${ }^{108}$ Later, this original effort to project a more secure self-image or image within his family extended to building an appropriate public image. This interpretation also fits with Hoover's later advice to an engineer friend to select for his autobiography what "holds public esteem."109

Since Hoover himself was the source of much of the confusion about his first teacher and his age, grade, and year he left West Branch, any explanation for these errors likely will not be final. There rarely is trustworthy and compelling evidence about the motives of anyone, alive or dead, even those who were both introspective and open about their inmost thoughts -and Hoover was neither.

Our knowledge and certainty about Hoover's involvement decrease as we go from his passive acceptance of the error that he attended a one-room school to the three congruous errors related to his schooling at the time he left West Branch, and finally to the confusions about his first teacher. The nature of Hoover's involvement with the error that Mollie Brown Carran was his first teacher likely will remain the greatest mystery. In any case, the tortuous history of distorted claims about Herbert Hoover's early schooling is a cautionary tale that suggests the importance of vigilance in preventing the distortion of the historical record, whether through carelessness, manipulation for political or public relations purposes, or psychological need.

108. Lyons, Hoover, 14.

109. Nash, Hoover the Engineer, 474, 512-13; Nash, Hoover the Master, ix, 3, 37677; Nash, Hoover the Humanitarian, 299-303, 411-13, 424-26, 469, 615nn. 
Copyright of Annals of Iowa is the property of State of Iowa, by \& through the State Historical Society of Iowa and its content may not be copied or emailed to multiple sites or posted to a listserv without the copyright holder's express written permission. However, users may print, download, or email articles for individual use. 